\title{
Properties of Lightweight Self-consolidating Fibre Reinforced Concrete
}

\author{
K.M. A. Hossain' ${ }^{1}$ I. N. Celasun' ${ }^{1}$ K.M. Y. Julkarnine ${ }^{1}$, M.A. Hossain ${ }^{1}$ \\ ${ }^{1}$ Ryerson University \\ 350 Victoria St, Toronto, Canada \\ ahossain@ryerson.ca; incelasun@ryerson.ca; kmyjulkarnine@ryerson.ca; mohammadali.hossain@ ryerson.ca
}

\begin{abstract}
This paper presents the influence of four different types of fibres such as Polyethylene (PE), Polyvinyl Alcohol (PVA), HighDensity Polyethylene (HDPE) and Crumb Rubber on various properties of lightweight self-consolidating fibre reinforced concrete (LWSCFRC). The influences of fibre types and dosages were evaluated based on slump flow, density, compressive/flexural strength and rapid chloride permeability characteristics. All concrete mixtures satisfied the criteria to be classified as structural LWSCC by exhibiting a slump flow and 28-day compressive strength of more than $500 \mathrm{~mm}$ and $17.8 \mathrm{MPa}$, respectively with a 28-day air dry density of less than $1840 \mathrm{~kg} / \mathrm{m}^{3}$. The compressive strength and slump flow of LWFRSCC mixtures decreased with the increase of fibre dosage. The good performance of LWSCFRC mixtures were reflected in terms of their lower compressive strength to flexural strength ratio, higher energy absorbing/toughness capacity and similar/better chloride permeability compared to their LWSCC counterpart (without fibre).
\end{abstract}

Keywords: Lightweight self-consolidating fibre reinforced concrete; Flowability; Strength; Chloride permeability

\section{Introduction}

Lightweight concrete (LWC) has been used to construct famous landmarks such as the Pantheon Dome and the Coliseum [1]. Self-consolidating concrete (SCC) has become a preferred choice for construction as this type of material can fill forms and gaps without the need for mechanical vibrations [2-4]. Throughout the years, engineers have started to realize the potential of improvement of concrete performance by adding fibres. Researches have shown that the addition of fibres into concrete can prevent damage due to shrinkage and micro-cracks. There are different categories of fibres such as naturally occurring, synthetics, glass and steel. Some popular types of synthetic fibres include polyethylene (PE), high density polyethylene (HDPE), polyester, polypropylene and polyvinyl alcohol (PVA) [5, 6]. To promote sustainable construction, protect the environment and for economy, researchers have started to use fibres from recycled materials such as waste pet bottles, plastic, glass and old tires in concrete mixes [3,7]. Over the last decades, research studies have been conducted on lightweight concrete, fibre reinforced concrete (FRC) and more recently, on the lightweight self-consolidating concrete (LWSCC) [8-15]. Lightweight self-consolidating fibre reinforced concrete (LWSCFRC) is a new technology that can combine benefits of LWSCC and FRC $[4,5,10,16]$. However, very limited research studies have been conducted on the effect of different types of fibres and their dosages on the properties of LWSCFRCs. There is a need to do research on the development of LWSCFRC mixtures with different types of fibres based on comprehensive investigations on fresh state, mechanical and durability properties. The current research at Ryerson University is a timely initiative which will definitely contribute to the development and performance evaluation of LWSCFRC mixtures. The main objective for this reasearch is to investigate the performance of various LWSCFRC mixtures made of different types of aggregates and fibres based on the fresh state, mechanical and durability properties.

This paper presents the results of a preliminary experiental investigation on the development and performance evaluation of LWSCFRC mixtures made with four different types of fibres namely polyethylene, polyvinyl alcohol, high density polyethylene and crumb rubber.

\subsection{Experimental Program}

Experimental investigations were conducted to demonstrate the effect of four different fibres (PE, PVA, crumb rubber and HDPE) on fresh state, mechanical and durability properties of eight LWSCFRC mixtures. The fresh state properties of 
all concrete mixtures were evaluated by conducting slump flow test and hardened properties were evaluated by testing density, compressive strength, flexural strength testing and resistance to chloride ion penetration.

\subsection{Materials and Properties}

ASTM Type 1 Portland cement with a specific gravity of 3.17, Class F fly ash with a specific gravity of 2.6, blast furnace slag fine aggregate, blast furnace slag coarse aggregate, dry densified silica fume and high-range water-reducing admixture (HRWRA) were used. Figure 1 shows fine and coarse slag aggregates and Table 1 presents the gradation of slag aggregates along with ASTM C330/C330M (2014) gradation guidelines.

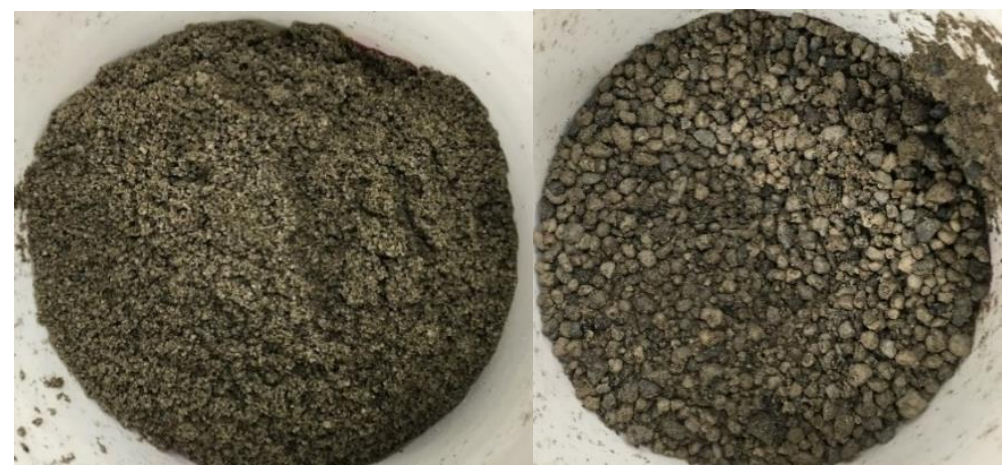

Fig. 1: Left: Fine slag aggregate; Right: Coarse slag aggregate

Table 1: Grading of slag aggregates

\begin{tabular}{|l|c|c|c|c|}
\hline \multirow{2}{*}{ Sieve size $(\mathrm{mm})$} & \multicolumn{3}{|c|}{ Percentage passing } \\
\cline { 2 - 5 } & \multicolumn{2}{|c|}{ ASTM C330 Guidelines } & Fine aggregate & Coarse aggregate \\
\cline { 2 - 5 } & Fine & Coarse & & \\
\hline 25 & - & - & - & 100 \\
\hline 12.5 & - & $90-100$ & - & 98.6 \\
\hline 9.5 & - & $40-80$ & - & 78.9 \\
\hline 4.75 & $85-100$ & $0-20$ & 100 & 23.5 \\
\hline 2.36 & - & $0-10$ & 66.9 & - \\
\hline 1.18 & $40-80$ & - & 32 & 10.6 \\
\hline 0.3 & $10-35$ & - & 3.2 & 3.4 \\
\hline 0.15 & $5-25$ & - & 2.2 & 1.2 \\
\hline 0.075 & - & $0-10$ & 0.3 & 0.5 \\
\hline Absorption $(\%)$ & - & - & 6.5 & 8.0 \\
\hline Dry Loose Bulk Density $\left(\mathrm{kg} / \mathrm{m}^{3}\right)$ & 1120 & 880 & 2250 & 1750 \\
\hline
\end{tabular}

Supplementary cementing materials (such as dry-densified silica fume and Class F fly ash) were used to assist in obtaining a workable and uniform concrete mixture. The silica fume normally provides benefits such as reducing bleeding, increasing strength and durability (BASF, 2016). Fly ash also provides better workability and increases resistance to sulphate [12]. In addition, reduced segregation of fresh concrete was observed with the use of Class F fly ash [4]. Overall, these two cementitious materials can provide enhanced mechanical and durability properties for the lightweight concrete. The highrange water-reducing admixture was used to provide benefits such as early strength development and slump retention. Four types of fibres with different material and geometric properties were used to develop LWSCFRCs and to investigate their performance based on fresh state, mechanical and durability properties. PVA, PE and HDPE fibres were white in color and had different lengths and diameters (Table 2). Crumb rubber (made from recycled tires by grinding) was black with a sand 
like texture and had a specific gravity of 0.9 [3]. Figure 2 shows PE, PVA, HDPE fibres as well as crumbed rubber used in this study.

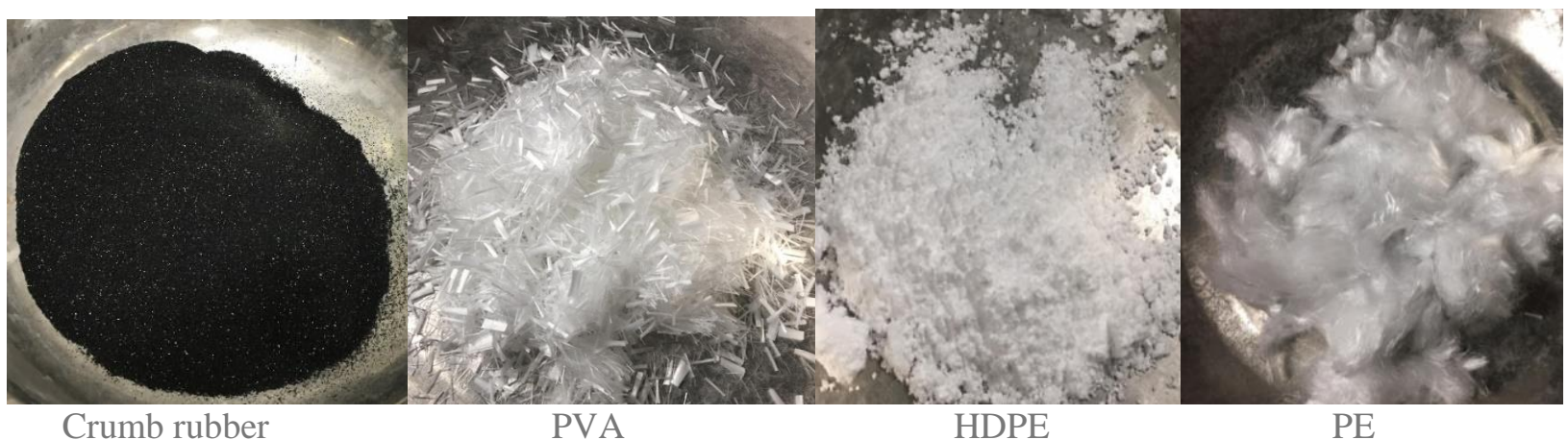

Fig. 1: Fibres and crumb rubber

Table 2: Fibre properties

\begin{tabular}{|l|c|c|c|c|}
\hline Fibre Type & Length $(\mathrm{mm})$ & Specific Gravity $\left(\mathrm{g} / \mathrm{cm}^{3}\right)$ & Melting Point $\left({ }^{\circ} \mathrm{C}\right)$ & Diameter (Microns) \\
\hline PVA & 8 & 1.3 & 225 & 38 \\
\hline PE & 13 & 0.93 & 123 & 2.2 \\
\hline HDPE & 0.1 & 0.96 & 135 & 5 \\
\hline
\end{tabular}

PVA: Polyvinyl alcohol, PE: Polyethylene; HDPE: High density polyethylene

\subsection{Concrete Mix Design}

Eight concrete mixtures (as presented in Table 3) were developed from a large number of trial mixtures using a control mixture without fibre. The objective was to have homogenous mixtures with good slump flow and workability when fibres were incorporated. As a result, water to cementing material ratio $(w / \mathrm{cm})$ and fine aggregate to coarse aggregate ratio varied slightly between the fibre types. The selection of the amount of fibre for each concrete $(0.125 \%$ to $1.0 \%)$ was based on trial and error and a lower value was selected that allowed better workability and less clumping of the fibres. During mixing, it was noticed that the control mixture was rather watery, to counteract this, more silica fume was added to reduce the bleeding and make the mixture more workable - thus the w/cm ratio was decreased to 0.33 . In addition to the control mixture, the $0.5 \%$ HDPE mixture needed an increased dosage of HRWRA to ensure a good workability.

Table 3: Concrete Mixture Proportions (Ratios by 1 part of cement)

\begin{tabular}{|l|c|c|c|c|c|c|c|c|l|}
\hline Concrete Mix ID & w/cm & $\begin{array}{c}\text { Type 10 } \\
\text { Cement }\end{array}$ & $\begin{array}{c}\text { Fly } \\
\text { Ash }\end{array}$ & $\begin{array}{c}\text { Silica } \\
\text { Fume }\end{array}$ & Water & $\begin{array}{c}\text { Coarse } \\
\text { Agg. }\end{array}$ & $\begin{array}{c}\text { Fine } \\
\text { Agg. }\end{array}$ & $\begin{array}{c}\text { HRWRA } \\
\left(\mathrm{kg} / \mathrm{m}^{3}\right)\end{array}$ & $\begin{array}{l}\text { Fibre } \\
\left(\mathrm{kg} / \mathrm{m}^{3}\right)\end{array}$ \\
\hline Control (no fibre) & 0.33 & 1 & 0.156 & 0.137 & 0.431 & 1.179 & 1.667 & 3.876 & - \\
\hline $0.5 \%$ PE & 0.35 & 1 & 0.156 & 0.094 & 0.437 & 1.179 & 1.667 & 4.750 & 4.85 \\
\hline $1.0 \%$ PE & 0.35 & 1 & 0.156 & 0.094 & 0.437 & 1.179 & 1.667 & 4.750 & 9.70 \\
\hline $0.5 \%$ HDPE & 0.4 & 1 & 0.156 & 0.094 & 0.506 & 1.179 & 1.640 & 7.50 & 4.80 \\
\hline $1.0 \%$ HDPE & 0.35 & 1 & 0.156 & 0.094 & 0.437 & 1.179 & 1.614 & 4.750 & 9.60 \\
\hline $0.5 \%$ Crumb Rubber & 0.35 & 1 & 0.156 & 0.094 & 0.437 & 1.179 & 1.640 & 4.750 & 4.50 \\
\hline $1.0 \%$ Crumb Rubber & 0.35 & 1 & 0.156 & 0.094 & 0.437 & 1.179 & 1.614 & 4.750 & 9.00 \\
\hline $0.125 \%$ PVA & 0.35 & 1 & 0.156 & 0.094 & 0.437 & 1.179 & 1.640 & 3.876 & 1.625 \\
\hline $0.25 \%$ PVA & 0.35 & 1 & 0.156 & 0.094 & 0.437 & 1.179 & 1.635 & 4.750 & 3.25 \\
\hline
\end{tabular}

$\mathrm{cm}=$ summation of cement, fly ash and silica fume; numeric in Mix ID represents \% of fibre; ratio by mass 


\subsection{Mixing, Casting and Curing}

Before the materials were mixed in the concrete mixer, coarse and fine slag lightweight (LW) aggregates were presoaked in water for approximately two days to make them saturated. The day of the mixing, the aggregates were made saturated surface dry. The mixing process as shown in Figure 3.3 was used to create the nine concrete mixtures. This procedure allowed for proper and sufficient mixing of the materials and allowed for the fibres to be fully dispersed and mixed uniformly within the concrete mixture.

\begin{tabular}{|l|l|l|l|l|}
\hline $\begin{array}{l}\text { Fine + Coarse } \\
\text { LW aggregates }\end{array}$ & $3 / 4$ water & Binder & $\begin{array}{c}1 / 4 \text { water }+ \\
\text { HRWRA }\end{array}$ & Mixing \\
\hline
\end{tabular}

Figure 3: Mixing procedure

Each of the concrete mixtures was used to cast $100 \times 200 \mathrm{~mm}$ cylinders and $50 \times 75 \times 360 \mathrm{~mm}$ beams to be used for mechanical and durability testing. After casting, the specimens were placed in a curing room with a temperature of $23 \pm 2{ }^{\circ} \mathrm{C}$ and a relative humidity of $90 \%$. The specimens were then demolded after 24 hours and kept in the curing room until testing. Curing of these specimens was conducted as per ASTM C192/C192M-2016 [17].

\subsection{Fresh State Concrete Testing}

The slump flow test for all the concrete mixtures was conducted as per ASTM C1611/C1611M -2014 [18]. The main purpose was to conclude if the concrete mixture was workable and the LWA was uniformly distributed without segregation or bleeding. This is an important test as there is a higher risk of segregation of lightweight aggregate and bleeding of the mix. Slump flow value was recorded as the mean diameter of the spread after the standard slump cone was lifted and concrete mix stopped spreading. Once the mix had stop spreading, a visual inspection was made to see signs of segregation or bleeding and to classify the mixture based on Visual Stability Index (VSI) as per ASTM C1611/ C1611M -2014 [18]. Fresh state and 28-day air/oven dry densities were determined to classify concrete mixtures as SCC based on criteria as per ACI Committee 213-2014 [1]. To find the oven dry density, procedure put forth by ASTM C567/ C567M -2014 [19] was followed.

\subsection{Mechanical and Durability Property Testing}

Compressive strength of concrete mixtures was determined at 7 and 28-days as per ASTM C39/ C39M-2016 [20] using $100 \mathrm{~mm}$ x $200 \mathrm{~mm}$ cylindrical specimens using a loading machine by using a loading rate of $1 \mathrm{~mm} / \mathrm{min}$. At least three cylinders were tested to failure for each age and crack patterns with failure modes were noted. Flexural strength of the concrete mixtures were determined as per ASTM C1609/ C1609M-2012 [21] using beam specimens (at least three specimens for each age) subjected to four point loading to failure using a servo-controlled hydraulic testing machine. This tested provided load/flexural stress-deformation response, toughness/energy absorption as the area under the load-deformation curve. The durability of concrete mixtures was determined based on 28-day rapid chloride permeability (RCP) test as per ASTM C1202 - 12 [22] using cylindrical disk specimens (100 mm diameter and $50 \mathrm{~mm}$ thick).

\subsection{Results and Discussions}

Fresh state, mechanical and durability properties of LWSCFRC mixtures obtained from the tests are presented and discussed compared to control LWSCC without fibre.

\subsection{Fresh State and Density Properties}

The slump flow values along with visual stability index (VSI) of concrete mixtures are compared in Table 4 . For all the concrete batches the VSI was a value 1, which means there was no segregation between the aggregate and the paste and the mix was stable according to ASTM C1611/ C1611M -2014 [18]. The increase in fibre content in the concrete mixture exhibited decreased slump flow, which resulted in decreased workability. The lower slump flow value is in $1.0 \%$ HDPE of $450 \mathrm{~mm}$. This is because during the mixing process of the mixture, the fibres had a tendency to clump together instead of 
mixing uniformly with the concrete paste. Therefore, the workability of the mixture decreased. The highest slump flow was recorded in the $1.0 \%$ Crumb rubber specimen. $0.5 \%$ and $1.0 \%$ Crumb Rubber mixtures revealed more bleeding around the edges in the slump flow test. This is due to the plastic nature of the crumb rubber where the absorption capacity of the fibres is much lower. In conclusion, $0.5 \% \mathrm{HDPE}, 0.5 \%$ and $1.0 \%$ Crumb Rubber specimens exhibited better slump flow performance compared with the control specimen, therefore this can be an advantage from a self-consolidating point of view.

Table Error! No text of specified style in document.4: Slump flow, fresh state/air dry/oven dry density and compressive strength of concrete mixtures

\begin{tabular}{|l|l|l|l|l|l|l|l|}
\hline $\begin{array}{l}\text { LWSCC/LWSCFRC } \\
\text { Specimen Type }\end{array}$ & $\begin{array}{l}\text { Slump } \\
\text { flow } \\
(\mathrm{mm})\end{array}$ & $\begin{array}{l}\text { Fresh } \\
\text { density } \\
\left(\mathrm{kg} / \mathrm{m}^{3}\right)\end{array}$ & $\begin{array}{l}\text { Air dry } \\
\text { density } \\
\left(\mathrm{kg} / \mathrm{m}^{3}\right)\end{array}$ & $\begin{array}{l}\text { Oven dry } \\
\text { density } \\
\left(\mathrm{kg} / \mathrm{m}^{3}\right)\end{array}$ & VSI & \multicolumn{2}{|c|}{$\begin{array}{l}\text { Compressive strength }\left(\mathrm{f}_{\mathrm{c}}{ }^{\prime}\right) \\
(\mathrm{MPa})\end{array}$} \\
\cline { 5 - 9 } Control & 600 & 1926 & 1835 & 1780 & $1^{*}$ & $27.0 \pm 0.4$ & $45.0 \pm 1.5$ \\
\hline $0.5 \%$ PE & 556 & 1713 & 1637 & 1691 & $1^{*}$ & $13.1 \pm 0.1$ & $22.2 \pm 0.4$ \\
\hline $0.5 \%$ HDPE & 650 & 1900 & 1810 & 1756 & $1 *$ & $17.9+0.5$ & $34.6 \pm 2.1$ \\
\hline $0.5 \%$ Crumb Rubber & 680 & 1923 & 1836 & 1781 & $1^{*}$ & $41.7 \pm 0.4$ & $29.2 \pm 1.8$ \\
\hline $0.125 \%$ PVA & 630 & 1932 & 1840 & 1785 & $1^{*}$ & $28.1 \pm 0.4$ & $31.3 \pm 1.8$ \\
\hline $1.0 \%$ PE & 550 & 1795 & 1750 & 1711 & $1^{*}$ & $12.1 \pm 1.0$ & $18.2 \pm 1.0$ \\
\hline $1.0 \%$ HDPE & 555 & 1932 & 1840 & 1785 & $1^{*}$ & $23.2 \pm 0.1$ & $33.8 \pm 0.2$ \\
\hline $1.0 \%$ Crumb Rubber & 750 & 1900 & 1810 & 1756 & $1^{*}$ & $27.5 \pm 1.0$ & $37.0 \pm 3.1$ \\
\hline $0.25 \%$ PVA & 580 & 1921 & 1830 & 1775 & $1^{*}$ & $20.3 \pm 0.2$ & $26.2 \pm 0.2$ \\
\hline
\end{tabular}

*1: Stable with no segregation and slight bleeding

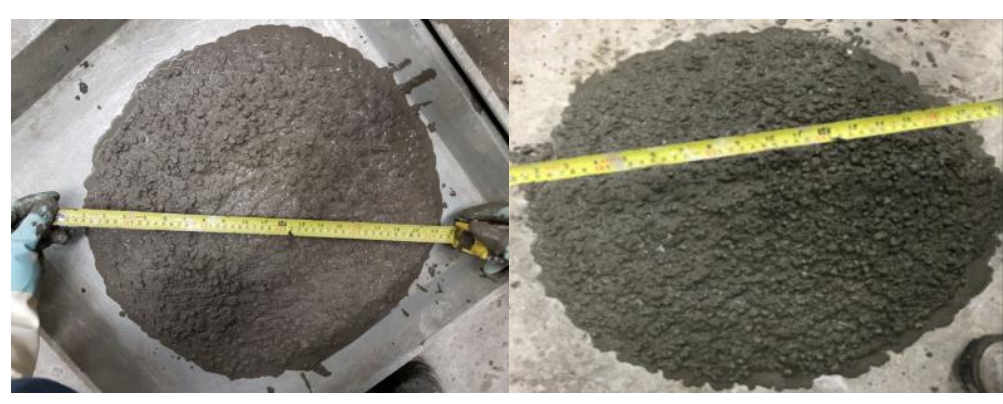

$0.5 \%$ PE Concrete
$0.25 \%$ PVA Concrete

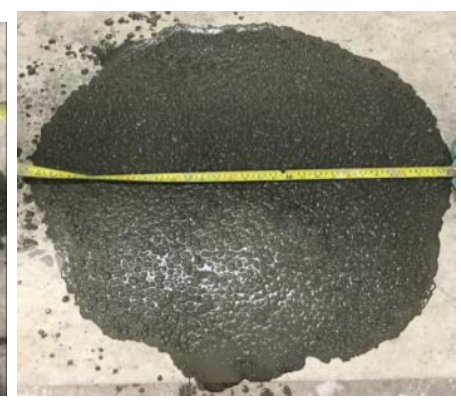

$1.0 \%$ Crumb Rubber Concrete

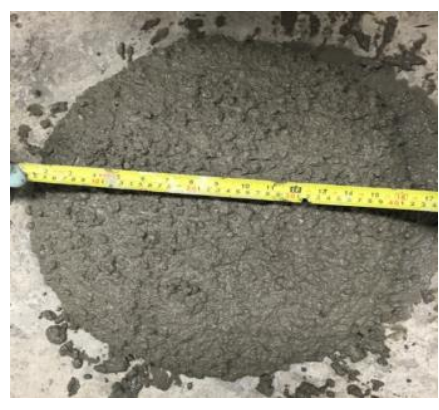

$1.0 \%$ HDPE Concrete

Fig. 4: Typical slump flow of LWSCFRC mixtures

A visual representation of slump flow for $0.5 \%$ PE, $0.25 \%$ PVA, $1 \%$ Crumb Rubber and 1\% HDPE is shown in Figure 4. The addition of fibres overall decreases the workability, but all concrete mixtures satisfied the minimum slump flow requirement of $550 \mathrm{~mm}$ (slump flow values ranged between $550 \mathrm{~mm}$ and $750 \mathrm{~mm}$ ) and qualified as SCC (Table 4).

Table 4 presents that fresh state and 28-day air dry/oven dry densities of the concrete mixtures. To classify as lightweight concrete, air dry density should be less than or equal to $1840 \mathrm{~kg} / \mathrm{m}^{3}$ as per ACI 213R [1]. Overall, the addition of fibres in a concrete mixture increased the density of the mixture compared to the control mixture. All the mixtures reached the 28-day air dry density of less than $1840 \mathrm{~kg} / \mathrm{m}^{3}$ and classified as LWSCC.

\subsection{Hardened Properties}

Table 4 summarizes 7 - and 28-day compressive strength ( $\left.f_{c}{ }_{c}\right)$ of all concrete mixtures showing the variation in the results based on companion samples. As per ACI 318 -2014 [23] to qualify as structural LWSCC, the 28-day compressive strength should be at least 17.2 MPa. All the mixtures reached the 28-day compressive strength of more than 17.2 MPa and air dry density of less than $1840 \mathrm{~kg} / \mathrm{m}^{3}$ and can be classified as structural LWSCC. 


\subsubsection{Compressive Strength}

Increase of PE fibre content from $0.5 \%$ to $1.0 \%$ decreased the compressive strength and also the addition of PE fibre decreased the compressive strength compared to control ( $0 \%$ fibre) (Table 4 ). This might be associated with the clumping (more paste was absorbed into these clumps) and non-uniform distribution of PE fibre which can negatively affect the mechanical properties. The 7-day compressive strength of 0.5\% HDPE mixture was 17.8 MPa compared to 23.2 MPa of 1.0\% HDPE mixture (showing an increase in early age strength) while no significant difference (varying from $34.6 \mathrm{MPa}$ to $33.8 \mathrm{MPa}$ ) was observed at 28-day. The similar observation was recorded in other research an increase in HDPE fibre dosage from $0.2 \%$ to $0.6 \%$ produced a compressive strength of $32 \mathrm{MPa}$ and $35 \mathrm{MPa}$, respectively [24]. The shorter length of the HDPE fibres (compared to PE fibres) allowed better dispersion, less air void formation, formation of a denser matrix and hence, higher compressive loading [24]. Overall, addition of HDPE fibre reduced compressive strength compared to control. Both $0.5 \%$ and $1.0 \%$ HDPE satisfy the criteria for structural LWSCC.

Increase of crumb rubber content from $0.5 \%$ to $1.0 \%$ decreased both the 7-day (from 29.2 MPa to $27.0 \mathrm{MPa}$ ) and 28day (45.0 MPa to 41.7MPa) compressive strength. The addition of crumb rubber did not improve (similar or lower strength) the compressive strength which can be attributed to the poor/weak rubber fibre-paste cohesion. Previous research studies on rubberized SCC concrete also showed a decrease in 28-day compressive strength from 35.6 MPa to 21.1 MPa with the increase in crumb rubber content from $10 \%$ to $30 \%$ [3]. In another study, the 28-day compressive strength was also decreased from $42 \mathrm{MPa}$ to $9 \mathrm{MPa}$ when the crumb rubber content increased to 25\% [11]. The increase in PVA fibres from $0.125 \%$ to $0.25 \%$ decreased compressive strength at 7-day (28.1 MPa to 20.3 MPa) and 28-day (31.3 MPa to 26.2 MPa). It is also confirmed from previos research studies that the increase of PVA fibre content from $0.15 \%$ to $0.30 \%$ produced a minor improvement of 28-day compressive strength of SCC mixtures from $38 \mathrm{MPa}$ to $40 \mathrm{MPa}$ [6].

Table 5: Flexural strength, Toughness and rapid chloride permeability (RCP) of concrete mixtures

\begin{tabular}{|l|c|c|c|c|c|}
\hline \multirow{2}{*}{ Specimen } & $\begin{array}{c}\text { Modulus of rupture/flexural } \\
\text { strength }\left(\mathrm{f}^{\prime} \mathrm{t}\right)(\mathrm{MPa})\end{array}$ & $\begin{array}{c}\text { Ratio } \\
\left(\mathrm{f}^{\prime}{ }_{\mathrm{c}} / \mathrm{f}^{\prime} \mathrm{t}\right)\end{array}$ & $\begin{array}{c}\text { Energy/ toughness } \\
(\text { Joules })\end{array}$ & \multicolumn{2}{|c|}{$\begin{array}{c}\text { 28-day rapid chloride } \\
\text { permeability (RCP) }\end{array}$} \\
\cline { 2 - 6 } & 28 -day & & 28 -day & Rating \\
\hline Control (without fibre) & 3.30 & 13.6 & 0.36 & 1070 & Low \\
\hline $0.5 \%$ PE & 2.40 & 10.4 & 0.31 & 2560 & Moderate \\
\hline $0.5 \%$ HDPE & 3.34 & 11.2 & 0.31 & 1668 & Lery Low \\
\hline $0.5 \%$ Crumb Rubber & 2.61 & 10.2 & 0.46 & 1094 & Low \\
\hline $0.125 \%$ PVA & 3.06 & 8.6 & 0.32 & 3230 & High \\
\hline $1.0 \%$ PE & 2.10 & 10.2 & 0.46 & 2096 & Moderate \\
\hline $1.0 \%$ HDPE & 3.31 & 10.6 & 0.33 & 1398 & Low \\
\hline $1.0 \%$ Crumb & 3.49 & 9.1 & 0.41 & 1429 & Low \\
\hline $0.25 \%$ PVA & 2.89 & & &
\end{tabular}

The increase in PVA fibres caused workability of mixtures to decrease significantly even with increased dosage of HRWRA due to the clumping of fibres and segregation and as a result, it was not possible to use higher dosages $(0.5 \%$ or $1.0 \%)$ as used for other fibres. The decrease/not significant increase increase in the development of compressive strength from 7 and 28days has also been noticed in other research with different fibres such as steel fibres and polypropylene fibres (PP) in one research study with the increase of steel fibres from $30 \%$ to $60 \%$ fibre content [5, 12]. Previous literature has revealed that the use of silica fumes can allow for a better bonding of the paste, lightweight aggregate and fibre (reducing segregation) creating a denser mixture, therefore enhancing the compressive strength [4,11]. Overall, it can be seen from Table 4 that the use of fibres did not enhance the compressive strength and an increase in fibre content reduced the compressive strength as noted in PVA, PE, HDPE and Crumb Rubber mixtures in this study.

It was found that due to porous/weak nature of the lightweight aggregate, specimen produced with PE, PVA, HDPE and control (no fibre) failed due to aggregate failure while those with crumb rubber failed due to bonding failure (because of 
weak paste-fibre-aggregate bond). Specimens with PE and PVA mixtures did show cracking but the specimen was still intact with no fibre pull out but fibre ruptured. However, fibre pull out was observed in specimens made with HDPE mixture.

\subsubsection{Flexural Strength/Modulus of Rupture}

Flexural strength/modulus of rupture and toughness (calculated based on the area under the flexural load-deflection curve) concrete mixtures are summarized in Table 5. Flexural strength of concrete mixtures ranged between $2.10 \mathrm{MPa}$ and 3.30 MPa with a deviation of about $\pm 0.2 \mathrm{MPa}$ in companion samples. Although fibre addition decreased the flexural strength, the compressive to flexural strength ratios of fibre reinforced concrete mixtures (ranged between 8.6 and 11.2) are lower than the control mixture without fibre (13.6). This showed the beneficial effect of fibre addition in increasing the flexural strength compared to compressive strength. The fibre addition seemed to have no negative effect on the toughness/energy absorbing capacity of the LWSCFRC concrete mixtures compared to the control mix without fibre (Table 5). However, PVA mixtures exhibited higher toughness than control and other fibre reinforced mixtures. This may be due to strain hardening and fibre bridging behavior of PVA mixtures

\subsubsection{Rapid Chloride Permeability}

Table 5 summarizes the RCP values and rating of all concrete mixtures LWSCFRC as per ASTM C1202 [22]. Overall, the increase in fibre content increased the permeability with PE fibres providing the worst behavior. The ideal concrete mixture that can provide the optimal durability against chloride ion penetration (very low) is a mixture with $0.5 \%$ HDPE. Other researchers also concluded that the increase in crumb rubber content increased the chloride ion penetration depth [11].

\section{Conclusions}

The following conclusions are drawn from the study:

- The increase in fibre content decreased the workability and the three mixtures that provided a higher slump flow were made of 1.0\% Crumb Rubber, 0.5\% Crumb Rubber and 0.5\% HDPE with slump flow values of 750, 680 and $650 \mathrm{~mm}$, respectively.

- There was not much improvement to the compressive and flexural strengths by the addition of fibres. The 28-day compressive strength of all LWSCFRC specimens was found to be lower than the control specimen (without fibre). The top three LWSCFRC mixes that had the highest compressive strength were f $1.0 \%$ Crumb Rubber, 0.5\% HDPE and 1.0\% HDPE with 37, 35 and $34 \mathrm{MPa}$, respectively. The top three LWSCFRC mixes with the highest flexural strength were made of $1.0 \%$ Crumb Rubber, 0.5\% HDPE, and 1.0\% HDPE with 3.5, 3.4 and 3.3 MPa, respectively.

- All concrete mixtures satisfied criteria for structural LWSCFRC based on slump flow, density and compressive strength.

- Rapid chloride permeability LWSCFRC mixtures ranged from low to moderate with PVA and crumb rubber mixtures showing lowest permeability.

- Comprehensive research are ongoing concentrating on the fresh state (rheology and workability), mechanical (strength, and bond characteristics), durability (RCP, freeze-thaw, fire resistance, acid/chloride/sulphate resistance, thermal properties ), micro-structure and structural performance using different types of aggregates.

\section{Acknowledgements}

The authors acknowledge the financial support from Natural Sciences and Engineering Research Council, Canada.

\section{References}

[1] ACI Committee 213. (2014). A213R-14 Guide for Structural Lightweight-Aggregate Concrete. Farmington Hills: American Concrete Institute, USA.

[2] Mazaheripour, H., Ghanbarpour, S., Mirmoradi, S. H., \& Hosseinpour, I. (2011). The Effect of Polypropylene Fibres on the Properties of Fresh and Hardened Lightweight Self-Compacting Concrete. Construction and Building Materials, 25(1), 351-358.

[3] Karahan, O., Ozbay, E., Hossain, K.M. A., Lachemi, M., \& Atis, C. D. (2012, July/August). Fresh, Mechanical, Transport and Durability Properties of Self-Consolidation Rubberized Concrete. ACI Materials Journal, 109(4), 413-420. 
[4] Lotfy, A., Hossain, K.M.A, \& Lachemi, M. (2016). Durability Properties of Lightweight Self-Consolidating Concrete Developed with Three Types of Aggregates. Construction and Building Materials, 106, 43-54.

[5] Doukakis, J. P. (2013). Lightweight Self Consolidating Fiber Reinforced Concrete. Ann Arbor: ProQuest.

[6] Hossain, K. M.A, Lachemi, M., Sammour, M., Sonebi, M. (2013). Strength and Fracture Energy Characteristics of SelfConsolidating Concrete Incorporating Polyvinyl Alcohol, Steel and Hybrid Fibres. Construction and Building Materials, 45, 20 - 29.

[7] Foti, D. (2013). Use of Recycled Waste Pet Bottles Fibers for the Reinforcement of Concrete. Composite Structures, 96, 396-404.

[8] Hossain, K.M.A. (2004). Properties of Volcanic Pumice Based Cement and Lightweight Concrete. Cement and Concrete Research, 34(2), 283-291.

[9] Gupta, K., \& Singla, S. (2014). Improving Mechanical Properties of Self Compacting Light Weight Concrete on Mixture (SCLWC) with Fiberglass. International Journal of Civil Engineering, 1(1), 1-2.

[10] Gonen, T. (2015). Mechanical and Fresh Properties of Fiber Reinforced Self-Compacting Lightweight Concrete. Scientia Iranica, 22(2), 313-318.

[11] Gesoglu, M., \& Guneyisi, E. (2007). Strength Development and Chloride Penetration in Rubberized Concretes with and without Silica Fume. Materials and Structures, 40(9), 953-964.

[12] Gencel, O., Ozel, C., Brostow, W., \& Martinez-Barrera, G. (2011). Mechanical Properties of Self-Compacting Concrete Reinforced with Polypropylene Fibers. Material Research Innovations, 15(3), 216-225.

[13] Hossain, K.M.A, Ahmed,S., \& Lachemi, M.(2011). Lightweight Concrete Incorporating Pumice Based Blended Cement and Aggregate: Mechanical and Durability Characteristics. Construction and Building Materials, 25(3), 1186-1195.

[14] Iqbal, S., Ali, A., Holschemacher, K., \& Bier, T. A. (2015). Mechanical Propoerties of Steel Fiber Reinforced High Strength Lghtweight Self-Compacting Concrete (SHLSCC). Construction and Building Materials, 98, 325-333.

[15] Kim, Y. J., Choi, Y. W., \& Lachemi, M. (2010). Characteristics of Self-Consolidating Concrete Using Two Types of Lightweight Coarse Aggregates. Construction and Building Materials, 24(1), 11-16.

[16] Corinaldesi, V., \& Moriconi, G. (2015). Use of Synthetic Fibers in Self-Compacting Lightweight Aggregate Concretes. Journal of Building Engineering, 4, 247-254.

[17 ASTM C192/C192M (2016). Standard Practice for Making and Curing Concrete Test Specimens in the Laboratory. West Conshohocken: ASTM International.

[18] ASTM C1611/C1611M (2014). Standard Test Method for Slump Flow of Self-Consolidating Concrete. West Conshohocken: ASTM International.

[19] ASTM C567/C567M (2014). Standard Test Method for Determining Density of Structural Lightweight Concrete. West Conshohocken: ASTM International.

[20] ASTM C39/C39M (2016). Standard Test Method for Compressive Strength for Cylindrical Concrete Specimens. West Conshohocken: ASTM International.

[21] ASTM C1609/C1609M (2012). Standard Test Method for Flexural Performance of Fiber-Reinforced Concrete (Using Beam with Third-Point Loading). West Conshohocken: ASTM International.

[22] ASTM C1202 (2012). Standard Test Method for Electical Indication of Concrete's Ability to Resist Chloride Ion Penetration. West Conshohocken: ASTM International.

[23] ACI Committee 318. (2014). 318-14 Building Code Requirments for Structural Concrete and Commentary. Farmington Hills: American Concrete Institute, USA. [24] Bhavi, B. K., Reddy, V. V., \& Ullagaddi, P. (2012). Effect of Different Percentages of Waste High Density Polyethylene (HDPE) Fibres on the Properties of Fibre Reinforced Concrete. Nature Environment and Pollution Technology, 11(3), 461-468. 